\title{
Documented records of two migratory bird species in the State of Pernambuco, North-East Brazil
}

\author{
J. L. Souza ${ }^{a}$, A. C. Queiroz ${ }^{b}$, G. A. Pereirac*, V. Leandro-Silva ${ }^{d}$, A. C. R. Souza ${ }^{d}$ \\ and S.M. Azevedo-Júnior ${ }^{a}$ \\ aPrograma de Pós-graduação em Ecologia, Laboratório de Ornitologia, Departamento de Biologia, \\ Universidade Federal Rural de Pernambuco - UFRPE, Rua Dom Manuel de Medeiros, s/n, \\ CEP 52171-900, Recife, PE, Brazil

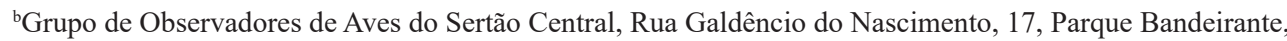 \\ CEP 56308-190, Petrolina, PE, Brazil \\ 'Laboratório de Ornitologia, Departamento de Biologia, Universidade Federal Rural de Pernambuco - UFRPE, \\ Rua Dom Manuel de Medeiros, s/n, CEP 52171-900, Recife, PE, Brazil \\ ${ }^{d}$ Licenciatura em Ciências Biológicas, Centro Acadêmico de Vitoria de Santo Antão - CAV, \\ Universidade Federal de Pernambuco - UFPE, Rua Alto do Reservatório, s/n, CEP 55608-680, \\ Vitória de Santo Antão, PE, Brazil \\ *e-mail: glaucoapereira@yahoo.com.br
}

Received: August 2, 2016 - Accepted: September 23, 2017 - Distributed: October 31, 2018 (With 2 figures)

The bird migration in the State of Pernambuco is a well documented phenomenon with some studies in the coastal region (Azevedo-Júnior, 1992, 1999; Azevedo-Júnior et al., 2001; Azevedo-Júnior and Larrazábal, 2002; Telino-Júnior et al., 2003) and in the Caatinga domain (Pereira and Azevedo-Júnior, 2013). In Pernambuco there are records of birds that perform Nearctic and Austral migration (Azevedo-Júnior and Larrazábal, 2002). Now we are reporting information about two documented records of two migratory bird species of the family Turdidae in the State of Pernambuco.

Veery Catharus fuscescens (Stephens, 1818)

It occurs and breeds on North American continent, migrating to South America from September to April (Collar, 2005). In Brazil most of the records are concentrated in the North region, but there are also records in the Central-West, South-East, and South region (Remsen Junior, 2001; Collar, 2005; Kaminski, 2011). In Pernambuco State, there was no mention of this species, but it was photographed in the neighboring State of Alagoas in the Ecological Station of Murici, in January 2011 (Pereira et al., 2012). One individual was photographed by ACQ in the west of State of Pernambuco, in an area of open caatinga vegetation, near the village of Bom Jardim, municipality of Petrolina $\left(9^{\circ} 21^{\prime} \mathrm{S}\right.$; 41 $30^{\prime} \mathrm{W}$ ), on November 29th 2015 (Figures 1a and b; WA1937544 and WA1937546).

Yellow-legged Thrush Turdus flavipes Vieillot, 1818

This species occurs in eastern Brazil, from State of Paraíba to State of Rio Grande do Sul (Sick, 1997), however, during the austral winter and fall it leaves the most northern regions of the Atlantic Forest (Sick, 1997; Collar, 2005). Therefore, it is considered an Austral migrant (Stotz et al., 1996), although Alves (2007) mentioned that it performs altitudinal or large-scale displacements. In the State of Pernambuco there are few records: Usina Sacramento, municipality of Água Preta, in which many individuals were observed and had their voices tape-recorded (Roda and Carlos, 2003); Mata de Duas Bocas, Usina Cucaú/Usina Santo André, municipality of Tamandaré, in which an individual was observed in September 2004 (Roda, 2004); and in the Pedra Danta/Frei Caneca Private Reserve, in the municipalities of Jaqueira and Lagoa dos Gatos, but the date and the amount of individuals has not been specified (Pongiluppi et al., 2016). One individual was captured and photographed, in the Ecological Station of Tapacurá $\left(8^{\circ} 03^{\prime} \mathrm{S} ; 35^{\circ} 13^{\prime} \mathrm{W}\right)$, municipality of São Lourenço da Mata, on June $28^{\text {th }} 2016$ (Figure 2). Then, this is the first photographic record of the species in the State of Pernambuco.

The Veery probably does not have many records due to discrete behavior and not sing in their wintering area (Ridgely and Tudor, 2009). Yellow-legged Thrush is also shy and it is a forest bird, registered mainly by its voice, or observed when it feeds on fruits (Sick, 1997; Ridgely and Tudor, 2009). Papers that published the records of these and others birds that perform migrations or displacements in the region are very important, given the need to know more about them, as their possible routes, environments, and subsequently draw up conservation plans (see Alves, 2007). 


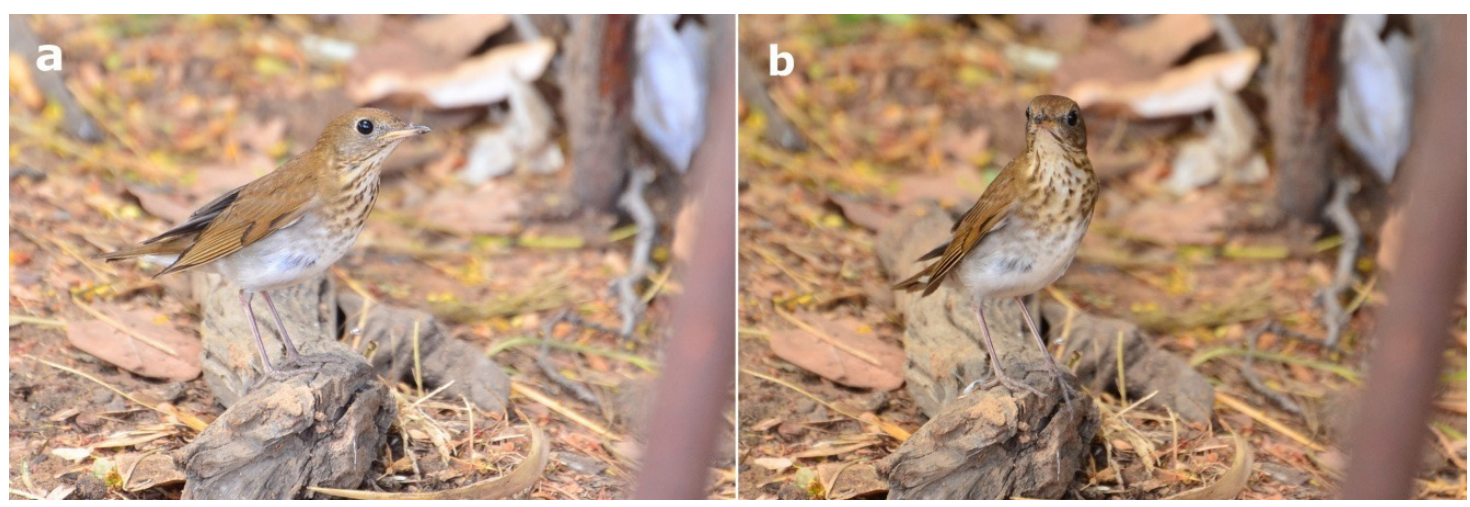

Figure 1. (a) and (b) Veery Catharus fuscescens photographed near the village of Bom Jardim, municipality of Petrolina, State of Pernambuco (Figures 1a and 1b; WA1937544 and WA1937546) (Photo by A.C. Queiroz).

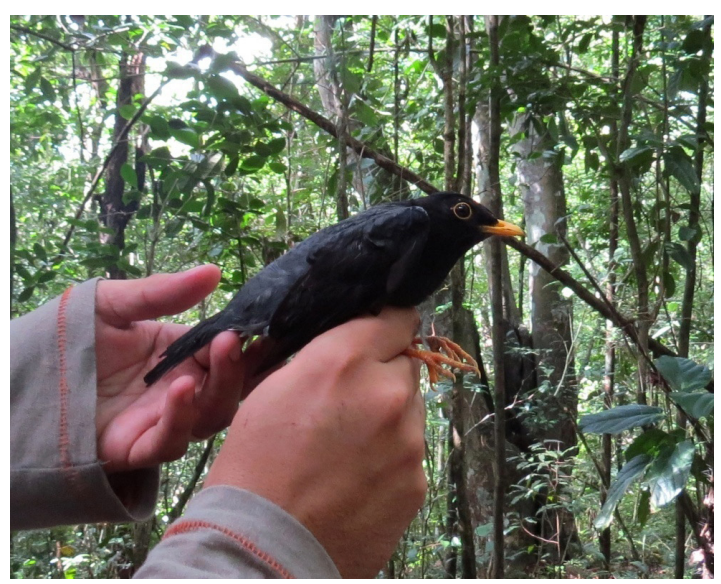

Figure 2. Yellow-legged Thrush Turdus flavipes photographed in the Ecological Station of Tapacurá, municipality of São Lourenço da Mata, State of Pernambuco (Photo by J.L. Souza).

\section{Acknowledgements}

We thank Stephen Jones, Roseli Pimentel, Odirlei Fonseca, and Octavio Campos Salles for the correct identification of the Veery. The first author would like to thank CAPES (Coordenação de Aperfeiçoamento de Nível superior) for support their research in the Ecological Station of Tapacurá.

\section{References}

ALVES, M.A.S., 2007. Sistemas de migrações de aves em ambientes terrestres no Brasil: exemplos, lacunas e propostas para o avanço do conhecimento. Revista Brasileira de Ornitologia, vol. 15 , no. 2 , pp. 231-238.

AZEVEDO-JÚNIOR, S.M., 1992. Anilhamento de aves migratórias na Coroa do Avião, Igarassu, Pernambuco, Brasil. Recife: Universidade Federal Rural de Pernambuco, pp. 31-47. Caderno Ômega Série Ciências Aquáticas, no. 3.
AZEVEDO-JÚNIOR, S.M., 1999. Migração de aves no litoral de Pernambuco, Brasil. São Carlos: Universidade Federal de São Carlos, 200 p. Tese de Doutorado em Ecologia.

AZEVEDO JÚNIOR, S.M., DIAS FILHO, M.M., LARRAZABAL, M.E., TELINO-JÚNIOR, W.R., LYRA-NEVES, R.M. and FERNANDES, C.J.G., 2001. Recapturas e recuperações de aves migratórias no litoral de Pernambuco, Brasil. Ararajuba, vol. 9 , no. 1 , pp. 33-42.

AZEVEDO-JÚNIOR, S.M. and LARRAZÁBAL, M.E., 2002. Migração de aves em Pernambuco. In: M. TABARELLI and J.M.C. SILVA, eds. Diagnóstico da biodiversidade de Pernambuco. Recife: SECTMA \& Editora Massangana, pp. 623-630.

COLLAR, N.J., 2005. Family Turdidae. In: J. DEL HOYO, A. ELLIOTT and D.A. CHRISTIE, eds. Handbook of the birds of the world. Barcelona: Lynx Ediciones, pp. 514-807. vol. 10.

KAMINSKI, N., 2011. First documented record of Veery Catharus fuscescens in southern Brazil. Cotinga, no. 33, pp. 98.

PEREIRA, G.A. and AZEVEDO-JÚNIOR, S.M., 2013. Variação sazonal de aves em uma área de caatinga no Nordeste do Brasil. Ornitologia Neotropical, no. 24, pp. 387-399.

PEREIRA, G.A., LOBO-ARAÚJO, L.W., LEAL, S., MEDCRAFT, J., MARANTZ, C.A., TOLEDO, M.T.F., ARAUJO, H.F.P., ALBANO, C., PINTO, T., SANTOS, C.H.A., SERAPIÃO, L.C.H., SILVA, G.B.M. and PIOLI, D., 2012. Important bird records from Alagoas, Pernambuco and Paraíba, north-east Brazil. Cotinga, vol. 34, pp. 91-95.

PONGILUPPI, T., TROIANO, B.F., GUSSONI, C.A. and DEVELEY, P.F., 2016 [viewed 2 August 2016]. Conservação das aves da Serra do Urubu [online]. São Paulo: SAVE Brasil. Available from: http://www.savebrasil.org.br/wp-content/ uploads/2015/03/Conserva\%C3\%A7\%C3\%A3o-das-Aves-daSerra-do-Urubu_SAVE-Brasil.pdf

REMSEN JUNIOR, J.V., 2001. The winter range of the veery (Catharus fuscescens): Lessons for determining winter ranges of species that winter in the tropics. The Auk, vol. 118, no. 4, pp. 838-848. http://dx.doi.org/10.1642/0004-8038(2001)118[0838:TW ROTV]2.0.CO;2. 
RIDGELY, R.S. and TUDOR, G., 2009. Field guide to the songbirds of South America: the Passerines. Austin: University of Texas Press. 750 p.

RODA, S.A. and CARLOS, C.J., 2003. New records for some poorly know birds of the Atlantic Forest in north-east Brazil. Cotinga, vol. 20, pp. 17-20.

RODA, S.A., 2004 [viewed 2 August 2016]. Aves da Usina Cucaú, Pernambuco [online]. Recife: CEPAN. Série Relatório da Avifauna, no. 2. Available from: http://cepan.org.br/uploads/ file/arquivos/234708f7d85ecf251965fc9618e4550f.pdf
SICK, H., 1997. Ornitologia brasileira. Rio de Janeiro: Nova Fronteira. $912 \mathrm{p}$.

STOTZ, D.F., FITZPATRICK, J.W., PARKER III, T.A. and MOSKOVITS, D.K., 1996. Neotropical birds: ecology and conservation. Chicago: The University of Chicago Press. 478 p.

TELINO-JÚNIOR, W.R., AZEVEDO-JÚNIOR, S.M. and LYRANEVES, R.M., 2003. Censo de aves migratórias (Charadriidae, Scolopacidae e Laridae) na Coroa do Avião, Igarassu, Pernambuco, Brasil. Revista Brasileira de Zoologia, vol. 20, no. 3, pp. 451-456. http://dx.doi.org/10.1590/S0101-81752003000300014. 